\title{
Understanding Analysis of Production Cost Calculation, Determining Sell Price, and Financial Literation of Industrial Businesses Continuity in Micro, Small and Medium Enterprise (MSME) in City of Pekanbaru
}

\author{
Eny Wahyuningsih Dian Saputra Yolanda Pratami* \\ Faculty of Economic, Universitas Islam Riau, Pekanbaru, Riau, Indonesia
}

\begin{abstract}
A micro, small and medium enterprise (MSME) becomes a special attention of the government to increase Indonesian economic sector. The development of MSME and creative economy will create a new economic resource and support regional economic development to provide a job, and MSME has high economic resilience too. In a practice, some problems often occur in cost-production calculation, the determining of sell price, and financial literacy that cause an error in calculating profit, so a business actor is wrong in analyzing the financial condition of the MSME. That condition encourages low business growth and even bankruptcy of MSME due to not being able to compete or experiencing acute Financial Distress. The development of the number of small subdistrict industries in Pekanbaru City has decreased significantly by 53\%. The number of small industries in 2016 amounted to 117 decreased to 54 units in 2017. Such a situation makes it necessary to pay special attention to understanding the calculation of production costs, determining selling prices and financial literacy among MSME sector players. The research method conducted here is a Qualitative method using a case study strategy in analyzing and applying it. The result of this study shows the lack of understanding of welding workshop owners related to the calculation of production costs, determining the selling price and financial literacy will have an impact on business continuity. This error - in analyzing costs and selling prices - causes it to be one of the factors of loss or inability to reach the break-even point of production, resulting in a loss and the inability of the company to remain competitive.
\end{abstract}

Keywords: Production Costs, Selling Prices, Financial Literacy, Business Continuity

DOI: $10.7176 /$ RJFA/11-6-09

Publication date:March $31^{\text {st }} 2020$

\section{Introduction}

\subsection{Background of the Problem}

One of the main objectives of each business unit formantion is survival (Going Concern) and the development of the company. Competition in the economic field has already come. Every business unit is required to be able to run a business very well. Tighter competition increasingly requires a business unit manager to take an appropriate action in order to maintain the viability of the business unit in accordance with the concept of "going concern". All activities undertaken to achieve these objectives must be supported by a good management condition as a manager. A performance of manager is measured by efficiency and effectiveness. Therefore, a manager is required to have an ability to analyze and use accounting data.

In obtaining an optimum profit as a step in determining the effectiveness and efficiency, especially for manufacturing companies, the role of the calculation of the cost of production and the calculation of the selling price is very important. Cost accounting in the calculation of cost of production plays the role of determining, analyzing and reporting cost items that support financial statements so that they can show reasonable data. Cost accounting provides cost data for various purposes. The costs incurred in the company must be classified and recorded properly, so as to enable the calculation of the cost of production carefully.

Every company needs to calculate production cost accurately and correctly, because without an accurate and correct calculation of the cost of production, the company will have problems in determining the selling price of a product. Practically, a manager is often wrong in determining the selling price by only using market price data as a benchmark. Whereas production costs sometimes exceed the average business of similar businesses. This error in analyzing costs and selling prices causes it to be one of the factors of loss or inability to reach the break-even point of production, resulting in a loss and the inability of the company to remain competitive.

Optimal profit earning cannot be separated from one's financial intelligence in utilizing the available resources. A person must have knowledge and skills in managing his personal economic resources effectively for his welfare. This ability is known as financial literacy. According to Vittet al. (2000) financial literacy is the ability to read, analyze, manage and communicate about a personal financial condition that will affect material well-being. Minimally understanding financial literacy in MSME sector causes some financial distress (Financial Distress) such as someone more likely to have problems with debt, misuse of credit, involved with higher credit costs, and less likely to plan for the future (Lusardi, 2010). 
MSME sector becomes a particular concern to the government in improving the Indonesian economy. This was explained by Agus Martowardojo as the Governor of Indonesia in the BI Creative Work Actor, Jakarta, Friday (18/8) "Development of MSME and creative economy will create new economic resources and encourage regional economic development to create jobs, and MSME also has high economic resilience ". Indra Bangsawan - the Head of the Riau Province Cooperative and MSME Office - the development of MSMEs in Riau, especially in Pekanbaru, has been assessed as not being able to develop various businesses, especially to face free competition in the Southeast Asian region in 2015 because of the limitations of knowledge in trying itself.

Based on data from the Central Statistics Agency, the development of small industries per district in Pekanbaru in 2017 decreased significantly from a total of 117 in 2016 to 54 in 2017 - A decrease of $54 \%$ in 2016 to 2017 - (Pekanbaru in figures: 2018). Based on information from the Head of Bank Indonesia Pekanbaru, Ismet Inono, loans disbursed by banks to MSME, BI data, continues to increase, but the arrears on the number of loans are also quite large. Non-performing loans of the micro small and medium business sector (MSME) were at 7.56 percent in the first three months of this year, an increase from Quarter IV / 2015 which was only 6.76 percent. The problems that have been described often occur in MSME sector due to lack of knowledge and low awareness of financial data and analyzing the financial data, resulting in low MSME growth. This situation makes it necessary to pay special attention to understanding the calculation of production costs, determining selling prices and financial literacy in MSME sector.

\subsection{Problem Formulation}

Lack of adequate knowledge in the calculation of production costs, determining the selling price (per unit) and financial literacy in small industries will lead to bankruptcy of MSME business in the city of Pekanbaru.

\section{Theoretical Study}

\subsection{Micro, Small and Medium Enterprise (MSME)}

Based on the Republic of Indonesia Law concerning criteria of Micro, Small and Medium Enterprises (MSMEs) Number 20 of 2008 ,

a) Micro Business

i. has a maximum net worth of Rp 50,000,000 (fifty million rupiah) excluding land and buildings for business premises; or

ii. has an annual sales result of at most Rp.300,000,000.00 (three hundred million rupiah)

b) Small business

i. has a net asset of more than $\mathrm{Rp} 50,000,000$ (fifty million rupiah) up to a maximum of $\mathrm{Rp}$ $500,000,000.00$ (five hundred million rupiah) excluding land and buildings for business premises; or

ii. has an annual sales result of more than Rp.300,000,000.00 (three hundred million rupiah) up to a maximum of Rp2,500,000,000.00 (two billion five hundred million rupiah).

c) Medium Business

i. has a net asset of more than Rp.500,000,000.00 (five hundred million rupiah) up to a maximum of Rp10,000,000,000.00 (ten billion rupiah) excluding land and buildings for business premises; or

ii. has an annual sales result of more than Rp2,500,000,000.00 (two billion five hundred million rupiah) up to a maximum of Rp50,000,000,000.00 (fifty billion rupiah).

\subsection{Accounting System and Cost of Production}

An accounting system is a method and procedure for recording and reporting financial information of a company or business organization. The main function of an accounting system is to produce timely, relevant and trustworthy information. The elements in the accounting system are interrelated, so data can be processed from the beginning to the final report.

The the cost of goods manufactured is often also called the cost of production. According to Raiborn and Kinney (2011) the cost of goods manufactured is the total production cost of goods that have been completed and transferred into the inventory of finished goods for a period. Production costs are classified into raw material costs, direct labor costs, and factory overhead costs. According to Hansen and Mowen (2017), the elements of production costs are direct raw material costs, direct labor costs and factory overhead costs.

In the job order costing system, each order must be made an order cost card written the name of the customer, the product ordered, the date of receipt of the order, the date of execution and the date of completion, and most importantly the details of production costs, selling price, and gross profit order.

\subsection{Selling Price}

Pricing is related to all short-term goals and long-term goals of a company. Price is related to sales revenue and pricing must be able to cover all costs in the company. Krismiaji and Aryani (2011) state that the general approach in determining selling prices is to add a markup percentage to the base price, also called cost-plus pricing. How to 
calculate markup is as follows:

$\%$ Markup $=($ non-production costs + desired profit $) /($ production costs $)$

\subsection{Financial Literacy}

The Organization for Economic Co-operation and Development (OECD) (2016) defines financial literacy as knowledge and understanding of financial concepts and risks, along with the skills, motivation, and confidence to make an effective financial decision, improve financial well being of individuals and society, and participate in the economic field.

\subsection{Business Continuity}

The company / business entity is an organization founded with the aim of maximizing the wealth of its capital owners (profitability) - besides, there are also another important goal namely, to maintain the sustainability of their business (survive) in competition. The objective of business sustainability can be interpreted as maximizing the welfare of the business entity which is the present value of the business entity to its future prospects. The principle of business sustainability assumes that the business entity will continue to operate throughout the project completion process, agreements and ongoing activities. Prediction of the sustainability of a business entity is very important for management and business entity owners to anticipate the possibility of potential bankruptcy, because bankruptcy involves the costs of both direct and indirect costs. Business sustainability is a condition when a company has sufficient funds to run and develop its business.

\section{Research Method}

3.1 Place and Time of Research

The research has focused on MSME of a small industrial unit namely Welding Workshop in Pekanbaru. The choice of welding workshop as an object of research is since this industry is a manufacturing entity whose characteristics are complex from raw materials, labor and overhead costs, thus causing difficulties in calculating production costs and selling prices.

\subsection{Sampling}

The population of this research is 41 welding shop businesses that spread in the city of Pekanbaru. Unit samples taken are as many as 10 welding workshop businesses by reason of researchers' taking the welding workshop business with small criteria.

\subsection{Data Analysis Technique}

\subsubsection{Data Reduction}

Obtained data regarding the welding shop owner's understanding of the calculation of production costs, determination of selling prices and financial literacy are quite complex. The answers from the interviews do not focus directly on the research problem. Therefore, the data reduction process is needed to select data that have meaning according to the focus and problem of the study.

\subsubsection{Categorization}

The next step is categorizing the interview result that has the same meaning. Furthermore, each categorization is given a name. The giving of a category name is based on the meaning contained in each sentence or paragraph that has been categorized and based on existing theories or previous research results. In categorization, one paragraph or one sentence can have more than one category. 
Table 1. Results of Data Categorization

\begin{tabular}{|c|c|c|c|}
\hline & \begin{tabular}{l|l} 
No & $\begin{array}{l}\text { Name } \\
\text { Welding } \\
\text { Workshop }\end{array}$ \\
\end{tabular} & of Calculation of Production Cost & $\begin{array}{l}\text { Determination } \\
\text { Selling Price }\end{array}$ \\
\hline 1 & $\begin{array}{l}\text { Rizky Welding } \\
\text { Workshop }\end{array}$ & $\begin{array}{l}\text { Raw material; The Combination of All Raw } \\
\text { Material Costs in one type of goods. } \\
\text { Direct labor; All wages for workers are } \\
\text { administrative labor (driver) combined with } \\
\text { production employee wages } \\
\text { Overheads; No Separation Calculation of fuel } \\
\text { cost consumption between the production process } \\
\text { and administrative purposes. }\end{array}$ & \begin{tabular}{|ll|l|}
$\begin{array}{l}\text { Calculate all used } \\
\text { materials including business uses its } \\
\text { employee wages }\end{array}$ & $\begin{array}{l}\text { Thn fund as it is } \\
\text { worried not being } \\
\text { able to r pay } \\
\text { installments More } \\
\text { money is saved and a } \\
\text { small investment. }\end{array}$ \\
\end{tabular} \\
\hline 2 & Kairos Teknik & $\begin{array}{l}\text { Raw material; The Combination of All Raw } \\
\text { Material Costs in one type of goods. } \\
\text { Direct labor; All wages for workers are } \\
\text { administrative (driver) labor combined with } \\
\text { production employees' wages. } \\
\text { Overheads; No Separation Calculation of the cost } \\
\text { of fuel consumption between the production } \\
\text { process and administrative purposes. }\end{array}$ & \begin{tabular}{|l|l|} 
Estimating the Cost of & Bhe Business is \\
Raw Materials, Labor & borrowing money \\
and Profit $(30 \%)$ & from bank and own \\
funds. Borrowed \\
money is to buy tools \\
and materials. \\
Excess is invested
\end{tabular} \\
\hline 3 & Hanguah Las & $\begin{array}{l}\text { Raw material; The Combination of All Raw } \\
\text { Material Costs in one type of goods. } \\
\text { Direct labor; All wages for workers are } \\
\text { administrative (driver) labor combined with } \\
\text { production employees' wages. } \\
\text { Overheads; No Separation Calculation of the cost } \\
\text { of fuel consumption between the production } \\
\text { process and administrative purposes. }\end{array}$ & \begin{tabular}{|l|l|}
$\begin{array}{l}\text { decreased } 30 \% \text { profit } \\
\text { from the base price }\end{array}$ & $\begin{array}{l}\text { Business is } \\
\text { borrowing money } \\
\text { from bank and own } \\
\text { funds. Excess money } \\
\text { is invested }\end{array}$ \\
\end{tabular} \\
\hline 4 & $\begin{array}{l}\text { Rio } \\
\text { Mandiri }\end{array}$ & $\begin{array}{l}\text { Raw material; The Combination of All Raw } \\
\text { Material Costs in one type of goods. } \\
\text { Direct labor; All wages for workers are } \\
\text { administrative (driver) labor combined with } \\
\text { production employees' wages. } \\
\text { Overheads; No Separation Calculation of the cost } \\
\text { of fuel consumption between the production } \\
\text { process and administrative purposes. }\end{array}$ & \begin{tabular}{|l|l|} 
Capital + how many \% & The Enterprise uses \\
that is desired + artisan & its own fund and it \\
does not have a + pair wages & $\begin{array}{l}\text { saving because the } \\
\text { profit is used to buy } \\
\text { raw materials }\end{array}$ \\
\end{tabular} \\
\hline 5 & $\begin{array}{l}\text { Bengkel } \\
\text { Keluarga }\end{array}$ & $\begin{array}{l}\text { as material; The Combination of All Raw } \\
\text { Material Costs in one type of goods. } \\
\text { Direct labor; All labor wages are given per week } \\
\text { or per month depending on the order. } \\
\text { Overhead; Fuel costs are for administrative } \\
\text { purposes only }\end{array}$ & 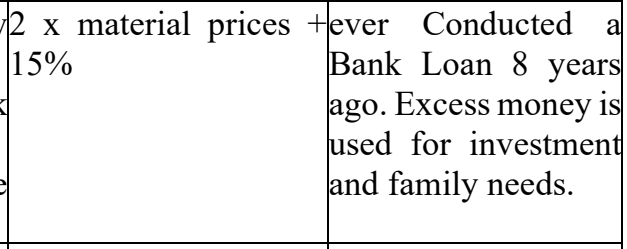 \\
\hline 6 & $\begin{array}{l}\text { Bengkel } \\
\text { Riau Maju }\end{array}$ & $\begin{array}{l}\text { Raw material; The Combination of All Raw } \\
\text { Material Costs in one type of goods. } \\
\text { Direct labor; All labor wages are given per } \\
\text { month. } \\
\text { Overhead Cost; No Separation Calculation of the } \\
\text { cost of fuel consumption between the production } \\
\text { process and administrative purposes. }\end{array}$ & $\begin{array}{l}\text { It depends on order } \begin{array}{l}\text { Using its own fund. } \\
\text { Excess money is } \\
\text { used for investment. }\end{array} \\
\\
\end{array}$ \\
\hline 7 & $\begin{array}{l}\text { Bengkel } \\
\text { Berkah }\end{array}$ & $\begin{array}{l}\text { as maw material; The Combination of All Raw } \\
\text { Material Costs in one type of goods. } \\
\text { Direct labor; All wages for workers are } \\
\text { administrative (driver) labor combined with } \\
\text { production employees' wages. } \\
\text { Overhead Cost; No Separation Calculation of the } \\
\text { cost of fuel consumption between the production } \\
\text { process and administrative purposes. }\end{array}$ & \begin{tabular}{|l}
$2 \times$ material prices + \\
$10 \%$ \\
made a loan to a \\
bank 10 years ago \\
because of lack of \\
funds. Needs money \\
for family needs.
\end{tabular} \\
\hline
\end{tabular}




\begin{tabular}{|c|c|c|c|c|}
\hline & \begin{tabular}{|l} 
Name \\
Welding \\
Workshop
\end{tabular} & of Calculation of Production Cost & $\begin{array}{l}\text { Determination } \\
\text { Selling Price }\end{array}$ & of|Financial Literacy \\
\hline 8 & $\begin{array}{l}\text { Bengkel } \\
\text { Amanah } \\
\text { Wijaya }\end{array}$ & $\begin{array}{l}\text { Las Raw material; The Combination of All Raw } \\
\text { Material Costs in one type of goods. } \\
\text { Direct labor; All labor wages are given per } \\
\text { month } \\
\text { Overhead Cost; No Separation Calculation of the } \\
\text { cost of fuel consumption between the production } \\
\text { process and administrative purposes. }\end{array}$ & $\begin{array}{l}2 \times \text { material prices } \\
10 \%\end{array}$ & $\begin{array}{l}\text { Using its own funds } \\
\text { and borrowing from } \\
\text { banks since 2018. } \\
\text { Installments are paid } \\
\text { on time and excess } \\
\text { money is for } \\
\text { investment and other } \\
\text { needs }\end{array}$ \\
\hline & Putra Mangg & \begin{tabular}{l|l|} 
ga 2 & Raw material; The Combination of All Raw \\
Material Costs in one type of goods. \\
Direct labor; All labor wages are given per week \\
depending on the order. \\
Overhead Cost; No Separation Calculation of the \\
cost of fuel consumption between the production \\
process and administrative purposes.
\end{tabular} & $\begin{array}{l}2 \times \text { material prices } \\
20 \%\end{array}$ & $+\mid \begin{array}{l}\text { Using its own funds } \\
\text { since } 2 \text { years ago. } \\
\text { Excess money for } \\
\text { investment }\end{array}$ \\
\hline & $\begin{array}{l}0 \text { Bengkel } \\
\text { Manulo } \\
\text { Kembar } \\
\text { Sejahtera }\end{array}$ & $\begin{array}{l}\text { Las Raw material; The Combination of All Raw } \\
\text { Material Costs in one type of goods. } \\
\text { Direct labor; All labor wages are given per week } \\
\text { depending on the order. } \\
\text { Overhead Cost; No Separation Calculation of the } \\
\text { cost of fuel consumption between the production } \\
\text { process and administrative purposes }\end{array}$ & $\operatorname{Cos} t+30 \%$ & $\begin{array}{|lr|}\text { Using its own funds } \\
\text { in oreder to not be } \\
\text { burdened } & \text { by } \\
\text { installments } & \text { and } \\
\text { borrowing } & \text { from } \\
\text { friends. } & \text { Excess } \\
\text { money is } & \text { for } \\
\text { investment. } & \\
\end{array}$ \\
\hline
\end{tabular}

Source: Processed Data, 2019

\section{Presentation of Findings}

This research finding report is the result of reduction, categorization and conclusion drawing from data that has been collected through interviews, observation and documentation. Writing data sources is marked by different codes to facilitate the researcher in presenting the result of the interview. The encoding " $\mathrm{N}$ " is the respondent, numbers 1, 2, 3 after ' $\mathrm{N}$ ' indicate the order of the respondent, I, 1 and " $\mathrm{a}$ " are numbers, the number after 'I' in the interview of the respondent is the number on the questionnaire. Example "N1.I.1a" means that the interview of the first respondent is number "I.1a." In addition to interviews, data also comes from documents. Supporting documents used are the recording and accounting of the welding shop business.

\subsection{Production Process and Accounting System}

The production process begins if there is an order from the customer. The product ordered is usually in the form of an iron fence, canopy, trellis and others. The production process starts from cutting steel bars, then formed, assembled, grinded, painted, finished and installed in the customer's residence. Production time usually ranges from 5 days to 7 days.

The accounting system in this welding shop business as a whole is still very simple bookkeeping combined in one book, so it should be made a special diary such as cash receipts, cash disbursement books, material purchase books, sales books, and made a general ledger with detailed accounts such as inventory materials, work-in-process inventory and finished-goods inventory, salary and wage expenses, factory overhead costs and details, sales revenue, cost of goods sold, and operating, equity and prive expenses. A good, complete, organized and detailed bookkeeping can make it easier for the entrepreneur in planning, controlling and making decisions.

Welding workshop business in the calculation of production costs uses cost calculations based on orders (job order costing). The characteristic of job order costing is that when an order comes, an order cost card is made to record the production costs and other data related to customer product orders. Raw material costs and direct labor costs are calculated based on costs that actually occur, while factory overhead costs are calculated using rates determined in advance.

In this welding workshop, most of enterpreneurs do not use an order fee card, but only record it simply in one book, and there are even entrepreneurs who do not record the cost of their products by the reason of having memorized the costs to be incurred.

\subsection{Calculation of Production Cost}

Production costs consist of 3 cost elements, namely "direct raw material cost, direct labor cost and factory 
overhead cost". Based on interviews, all business owners do not know that factory overhead costs (indirect production costs) must be included in the calculation of the cost of producing an ordered product. And they also don't understand the details of Factory overhead cost.

For this welding shop business, production cost can be grouped as follows:

Table 2. Grouping Production Cost in Welding Workshop Business

\begin{tabular}{|c|c|c|}
\hline No. & $\begin{array}{ll}\text { Component } & \text { of } \\
\text { Production Cost }\end{array}$ & Detail \\
\hline 1 & $\begin{array}{l}\text { Direct Raw Material } \\
\text { Cost }\end{array}$ & $\begin{array}{l}\text { Cost of steel bar, angle iron, steel plates, concrete steel, pipe, mild steel, hollow } \\
\text { steel, stainless steel, zinc, roofing, color paint and others }\end{array}$ \\
\hline 2 & Direct labor cost & $\begin{array}{l}\text { Labor wage for cutting, forming, assembling, grinding, painting, finishing, and } \\
\text { installation. }\end{array}$ \\
\hline 3 & $\begin{array}{l}\text { Factory overhead } \\
\text { costs: } \\
\text { a. indirect material } \\
\text { (helper) } \\
\text { b. factory equipment } \\
\text { c. other overhead costs }\end{array}$ & $\begin{array}{l}\text { a. Wire, "bentul", primer (paint) and others. } \\
\text { b. Tiner, gasoline, oil, LPG, glue, oxygen, sandpaper, putty, saw blade, grinding } \\
\text { stone, and others } \\
\text { c. Driver salary, supervisor / foreman, utility costs (electricity and water), } \\
\text { workshop rental fees, telephone cost, maintenance cost for production } \\
\text { equipment, equipment depreciation cost, depreciation cost for building } \\
\text { buildings (if own). }\end{array}$ \\
\hline
\end{tabular}

4.2.1 Calculation of Direct Raw Material Cost

Generally, the calculation of direct raw material cost by the welding shop business owners is appropriate, that is based on certain types of materials that are adjusted to the type of product ordered by the customer. Business owners usually estimate the cost of raw materials per meter based on market prices in accordance with the size and number of products to be made (in cost accounting this is called a standard cost). The goal is to determine the selling price to be given to customers (after added to wage costs and others).

4.2.2 Calculation of Direct Labor Cost (Wage Cost)

The calculation of wage cost as a whole uses a piece rate system. Each time getting a product order from a customer is done together. The amount of the wage depends on the level of difficulty of making the product, the duration of product processing, and the number of products worked. The total piece rate will be divided equally for each worker working on the order. Employers do not use certain wage standards, for example hourly wage standards based on the level of difficulty and type of product.

The goodness of the piece rate system is (a) encouraging workers to complete work as soon as possible, (b) the type of work and wages are known.

The disadvantages of a piece rate system in this business are (a) if it is not properly monitored, the quality of the work becomes poor, because it wants to be completed quickly, (b) the wages given are the same for each worker, thus creating injustice for workers whose working hours more, (c) there is no wage standard, as a result for certain types of orders, the wages may be too large or too small, and (d) do not separate the costs of direct wages and indirect labor costs such as salaries of delivery drivers and salaries administration section. Everything is charged to production costs, so this causes production costs to be too large.

4.2.3 Calculation of Factory Overhead Costs

Generally, welding workshop entrepreneurs do not understand the meaning of factory overhead cost. The type of "factory overhead cost" in this business can be seen in Table 2. Classifying production costs, based on the tabulated data, shows that the "factory overhead cost" that is charged with the cost of producing orders is only a small part such as production auxiliary materials (indirect materials), and factory equipment, while other factory overhead costs are not calculated into the cost of producing orders. This causes the production costs charged to customers to be too small while profit per order obtained becomes too large.

The way to charge the cost of indirect materials and plant equipment to order product in this welding workshop business is based on direct loading. They can do this because the production order received is generally not continuous, so indirect materials and equipment of the factory are purchased when it receives a product order, and is purchased in small quantities as needed. Actually, this method is not economical because purchasing in small quantities causes the purchase cost to be greater. This business should make supplies for indirect materials and plant equipment that are often used.

For the job order costing, "factory overhead cost" system is a shared cost that must be allocated to various ordered products. The way to allocate and charge "factory overhead cost" to each ordered product should use the tariff determined in advance. Business owners can use the previous month's cost data to prepare the "factory overhead cost" budget. Table 3 shows an example of a simple "factory overhead cost" tariff calculation (taken from monthly data) 
Table 3. Calculation of "factory overhead cost" Rates

\begin{tabular}{|l|l|l|l|}
\hline No & Overhead Fee Detail & Basic Charging & Overhead tariff calculation \\
\hline 1 & $\begin{array}{l}\text { Indirect Material Costs } \\
\text { (IM) }\end{array}$ & $\begin{array}{l}\text { Length of direct } \\
\text { raw material (M) }\end{array}$ & $\begin{array}{l}\text { IM rates = IM cost budget } \\
\text { Estimated total material length } \\
\text { (M) }\end{array}$ \\
\hline 2 & $\begin{array}{l}\text { Factory equipment costs and utility costs } \\
\text { (electricity and water) }\end{array}$ & Engine hours & $\begin{array}{l}\text { E\&U rates. = Equipment \& Utility } \\
\text { Budget } \\
\text { Estimated total engine hours }\end{array}$ \\
\hline 3 & $\begin{array}{l}\text { General Overhead Costs: Driver salaries, } \\
\text { foremen, workshop rental fees, telephone costs, } \\
\text { consumption costs, equipment maintenance } \\
\text { costs, equipment depreciation costs, building } \\
\text { depreciation costs (if the building is own) }\end{array}$ & $\begin{array}{l}\text { The hour of } \\
\text { direct labor }\end{array}$ & $\begin{array}{l}\text { General "factory overhead cost" } \\
\text { Rates = General factory overhead } \\
\text { cost Budget } \\
\text { Estimated Total DL Hours }\end{array}$ \\
\hline
\end{tabular}

Business owners can use one "factory overhead cost" rate on a certain basis, or use 3 types of "factory overhead cost" rates such as the example in Table 3 . The calculation of "factory overhead cost" rates can be done if the accounting system established by entrepreneurs is quite complete and orderly, so it makes easy to calculate "factory overhead cost" budgets and basic estimates loading. The way how to apply it is each production order must be determined (1) how many meters of direct raw material are used (IM tariff multiplied by the number of meters of ordered product), (2) how many hours of machine are used by each order (Equipment and utility tariffs multiplied by the number machine hours per order), and (3) how many hours of direct labor are used (General "factory overhead cost" rates multiplied by the number of DL hours)

Another requirement is that every welding shop business must be able to estimate how many orders will be received next month, or can also use last month's data. If the business is more advanced and developing, it can use the annual "factory overhead cost" rate and use the Activity Based Costing system.

\subsection{Determination of Selling Price.}

The selling price determination approach that is often used in manufacturing businesses is cost-plus pricing, wherein a predetermined markup percentage is added to the cost price figure to determine the selling price. The way to calculate with markup is:

$\%$ Markup $=($ non-production cost + desired profit $) /($ Production cost $)$.

Based on the data in Table 1, the method of determining the selling price in the welding shop business is divided into 2 ways, namely (1) selling price $=$ Material Cost + Labor Wage $+\%$ profit, with a variation in profit from $30 \%-40 \%(60 \%$ of 10 businesses $)$, (2) Selling price $=2 \mathrm{x}$ raw material price $+\%$ profit, with profit variation of $10 \%-20 \%$ ( $40 \%$ of 10 Enterprises).

Generally, determining the selling price in the first way is closer to the pricing theory, but the determination of the percentage of profit (markup) cannot be explained by the welding businessman, only based on past experience or estimates. this can cause the selling price to be too high or too low (not accurate). This can affect the level of competition with similar businesses, and also affect the amount of net profit each month.

While the second method of calculating the selling price is 2 times the price of the material plus the percentage of profit is a non-fundamental way. There is a way of determining the selling price based on the markup of the cost of the material if the material cost is the dominant factor and is the largest cost of production costs. The formula is as follows: markup direct raw material $=$ (direct labor cost + "factory overhead cost" + sales and administrative cost + operating profit) / direct raw material cost.

\subsection{Financial Literacy}

Based on an interview conducted with welding workshop respondents in Pekanbaru, from 10 respondents who were asked questions related to understanding financial literacy, it was found that $50 \%$ of the 10 welding shop owners preferred to use their own funds rather than borrowing funds from banks or other financial institutions to start businesses, and the others have borrowed from the bank.

Actually, there is a desire of the owner to make a loan at the bank, but due to the lack of level of knowledge of the welding shop owner on the benefits and risks and rights and obligations as a user of financial services, the owner prefers to use his own funds. To borrow funds from a bank, one of the conditions is to be able to prepare financial reports every month, while the welding shop entrepreneurs do not understand how to prepare financial reports, because they have never received very simple accounting and accounting training.

\subsection{Business Sustainability}

To assess the sustainability of the business, this welding workshop can be seen from 3 indicators, namely

1. The business experiences profit every period (monthly and yearly), and there is an increase in profits. According to entrepreneurs, there is an increase in profits of around $10 \%-25 \%$ every month. But the 
increase in profit should be known from the income statement which is compiled every month and every year. The entrepreneurs have never compiled the income statement, so the increase in profit is only an estimate.

2. An increase in order every month or every year.

According to the welding shop entrepreneurs, there is an increase in order every week. They can work around 3-4 work of making iron fences and others, while making canopy can be 20 meters per week or 80 meters per month, but it is not always consistent. An increase in order comes especially before the Eid or New Year. The increase in order should be seen from the sales report for each period, and also related to the income statement.

3. An increase in capital every month or every year.

The workshop owners also never compiled equity reports (capital reports) and statements of financial position, so it makes difficult to know whether there is an increase in capital or not. the entrepreneurs only say there is excess fund which has been invested.

Generally, the welding shop business have lasted for several years, and do not show any loss or potential bankruptcy. They assume that businesses can continue without borrowing fund in the bank.

\section{Conclusion}

Based on the result of the study can be concluded as follows:

1. Accounting system and calculation of production cost.

The owner of the welding workshop is right in determining the cost of direct raw materials, while the cost of direct labor cost is combined with indirect labor (the delivery of goods and administration). "factory overhead cost" is not entirely charged to the ordered product, which is charged only indirect materials and factory equipment. The way to charge them directly does not use the "factory overhead cost" rates specified in advance, so this can cause production costs to be too low.

2. Determination of Selling Price

The owner of the welding workshop determines the selling price of welding products based only on calculations according to the wishes of the owner. The owner only estimates and does not use the true costs. In addition, the owner also sets his own desired profit value without first calculating the $\%$ markup. This results in an inaccurate determination of selling prices.

3. Financial Literacy

Welding workshop owners who start a business prefer to use their own funds compared to borrowing money in banks or financial institutions on the grounds that they do not want to pay interest and are afraid of paying installments. This is because of the lack of level of knowledge of welding shop owners on the benefits and risks as well as their rights and obligations as financial service users. The owner can borrow money at a sharia bank that doesn't charge interest.

\section{References}

Arianta, D.K, dan Atmaja, A.T. (2017)."Analisis Perhitungan Biaya Produksi Pada Usaha Mikro, Kecil, Dan Menengah Jajanan Cita Rasa Khas Bali (Studi Kasus Ud. Sari Artha Kue, Kec. Banjar, Kab. Buleleng)”.ejurnal universitas Pendidikan ganesha. Volume 8 No. 2. Bali

Badan Pusat Statistik Kota Pekanbaru, Pekanbaru dalam Angka 2018

Hansen dan Mowen. (2017). "Dasar-dasar Akuntansi Manajerial Edisi 5", Salemba Empat, Jakarta

Mulyadi. (2015). “Akuntansi Biaya Edisi 5”. Yogyakarta: UPP-STIM YKPN.

Krismiaji, Y Anni Aryani. ( 2011). “Akuntansi Manajemen”. Yogyakarta: UPP-STIM YKPN.

Lusardi. Annamaria dan Olivia S. Mitchell. (2010). "Financial literacy and retirement preparedness: evidence and implications for Financial education program, Bussiness economic".

OECD. (2016). PISA 2015 “Assessment and Analytical Framework: Science, Reading, Mathematic and Financial Literacy”, PISA, OECD Publishing, Paris

Servon, L., \& Kaestner, R. (2008). "Consumer financi-al literacy and the impact of online banking on the financial behavior of lower-income bank customers". Journal of Consumers Affairs, 42(2), 271-305.

Vitt, L. A., Andersen, C., Kent, J., Lyter, D. M., Siegenthaler, J. K., \& Ward, J. (2000). "Personal finance and the rush to competence: Financial literacy education in the U.S". Virginia: Institute for Socio-Financial Studies.

Undang-Undang RI No 20 Tahun 2008 tentang Usaha Mikro, Kecil, dan Menengah 